Meta

Journal des traducteurs

Translators' Journal

\title{
From Operation to Action: Process-Orientation in Interpreting Studies
}

\section{Franz Pöchhacker}

Volume 50, numéro 2, avril 2005

Processus et cheminements en traduction et interprétation Processes and Pathways in Translation and Interpretation

URI : https://id.erudit.org/iderudit/011011ar

DOI : https://doi.org/10.7202/011011ar

Aller au sommaire du numéro

Éditeur(s)

Les Presses de l'Université de Montréal

ISSN

0026-0452 (imprimé)

1492-1421 (numérique)

Découvrir la revue

Citer cet article

Pöchhacker, F. (2005). From Operation to Action: Process-Orientation in Interpreting Studies. Meta, 50(2), 682-695. https://doi.org/10.7202/011011ar
Résumé de l'article

La notion du processus constitue une des idées clefs dans la réflexion systématique sur l'interprétation. Ainsi, différentes formes du méta-concept " processus " vont être passées en revue. En évoquant des modèles spécifiques du processus d'interprétation, le besoin d'une notion plus large de " processus » dans la recherche de l'interprétation va être le sujet de cette étude en soulignant tout particulièrement l'approche actiono-théorique de chercheurs allemands dans les années 1980 . Se basant sur un modèle interactif de la situation interprétative, l'auteur souligne l'importance de facteurs contextuels et cognitifs en indiquant des chemins par lesquels différentes approches conceptuelles peuvent être mises ensemble afin d'établir un avenir plus compréhensif des processus dans les études en interprétation. 


\title{
From Operation to Action: Process-Orientation in Interpreting Studies
}

\author{
FRANZ PÖCHHACKER \\ University of Vienna, Vienna, Austria \\ franz.poechhacker@univie.ac.at
}

\begin{abstract}
RÉSUMÉ
La notion du processus constitue une des idées clefs dans la réflexion systématique sur l'interprétation. Ainsi, différentes formes du méta-concept «processus» vont être passées en revue. En évoquant des modèles spécifiques du processus d'interprétation, le besoin d'une notion plus large de «processus » dans la recherche de l'interprétation va être le sujet de cette étude en soulignant tout particulièrement l'approche actionothéorique de chercheurs allemands dans les années 1980. Se basant sur un modèle interactif de la situation interprétative, l'auteur souligne l'importance de facteurs contextuels et cognitifs en indiquant des chemins par lesquels différentes approches conceptuelles peuvent être mises ensemble afin d'établir un avenir plus compréhensif des processus dans les études en interprétation.
\end{abstract}

\begin{abstract}
The notion of 'process' is identified as a prominent idea in systematic reflection on interpreting, and various incarnations of the 'process(ing) supermeme' are reviewed. With reference to selected models of the interpreting process, the need for a broader concept of 'process' in interpreting research is discussed, with special reference to the (inter)action-theoretical approach championed by German translation scholars in the 1980 . Based on an interactant model of the interpreting situation, the author highlights the relevance of contextual as well as cognitive factors and suggests ways in which various conceptual approaches can be reconciled to establish a more comprehensive sort of process-orientation in interpreting studies.
\end{abstract}

\section{MOTS-CLÉS/KEYWORDS}

process models, translation theory, interaction, situation, cognition

\section{Introduction}

Interpreting as the activity of enabling or facilitating communication between speakers of different languages is a millennial practice, with earliest records dating back some five-thousand years (cf. Hermann 1956/2002). Not so the systematic reflection and study of this phenomenon, which can be traced back only some five decades. And yet, fifty years of scholarly pursuit are impressive in their own right and have yielded a growing body of ideas and insights. Many of these have been brought to the attention of translation and interpreting scholars and practitioners through publication in Meta, whose fifty years of existence roughly coincide with the history of research on interpreting. It seems particularly appropriate, therefore, to devote this article in the journal's anniversary issue to a review of ideas about interpreting, with a focus on the notion of 'process' chosen as the overarching theme. 
I will begin by tracing some influential ways of thinking about the phenomenon of interpreting, most of which can be shown to involve the notion of 'process,' or 'processing.' The process(ing) "supermeme" (Chesterman 1997) of interpreting will then be analysed in more detail with reference to the concept of 'process' as such and to various models of interpreting in the literature. Having identified tripartite models of interpreting as a prominent theme, I will sketch a conceptual development that leads from a 'process' narrowly defined as a set of operations performed on linguistic input, to a comprehensive view of the process of communicative interaction. Special consideration will be given to the action-theoretical framework championed by German translation scholars in the 1980s and to the multiple ways in which the functionalist approach to translation and interpreting can be related to insights in sociology, socio-linguistics and communication studies. I will therefore conclude with a suggestion on how various ways of seeing and modelling interpreting could be reconciled in an integrative perspective.

\section{Interpreting is...}

In the history of scholarship on translation, few authors have reflected specifically on what we now call 'interpreting' (cf. Pöchhacker 2004: 11). From Cicero's famous distinction between translating ut interpres and ut orator to Luther's diatribe against literalism in his Sendbrief vom Dolmetschen (cf. Robinson 1997), the focus was on (written) translation, irrespective of the deceptive appearance of terms such as Latin interpres and German dolmetschen. One of the few pre-twentieth-century authors who bothered to write about (oral) 'interpreting' at some length was the German theologian Friedrich Schleiermacher. Using 'interpreting' as an antithesis to the translation of scholarly and artistic works, Schleiermacher (1813/1997: 227) disparagingly described it as "a merely mechanical task." As in St Jerome's description of verbatim rendition as verbum exprimere e verbo, this view of interpreting (and nonliterary translation) foregrounds a process operating on words, a rendering of verbal material in the words of another language. While the idea of a language conversion operation, or 'verbal transfer', is a deeply rooted conception of translation in general (cf. Chesterman 1997: 20), what Schleiermacher pointedly associated with 'interpreting' (Dolmetschen) appears to have stuck in many a scholar's mind. Julius Wirl (1958), for instance, in his early speculation on the processes of translation and interpreting, characterized the latter as an all but automatic operation between interconvertible languages.

Saussure's conception of language as a system (langue) would have made the explication of such 'language switching' a matter of linguistic theory. Indeed, scholars of the so-called Leipzig School of translation studies sought to apply lexical equivalence relations as well as syntactic correspondence rules to their account of the (simultaneous) interpreter's processing of the "chain of linguistic signs" (Kade and Cartellieri 1971). Contemporary psycholinguists, too, were investigating interpreting primarily as a process of converting a linguistic input into a linguistic output (e.g. Treisman 1965, Goldman-Eisler 1972).

This conception is neatly captured in the basic model by Daniel Gile (1994a: 40) of "a process $\mathrm{P}$ acting on an input I and producing an output O." 
FIGURE 1

Input-output process(ing) model

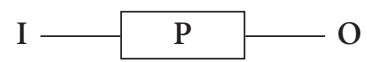

The generic process structure depicted in Figure 1 can be instantiated for various types of input and output. As described above, the input (and output) may be thought of as linguistic units, as lexical items and syntactic structures. This view of interpreting as an essentially linguistic process can be found also in the much-quoted essay by Roger Glémet (1958), a senior conference interpreter who held that interpreters transfer speeches "with the same faithfulness as sound-amplification" (1958: 106) and saw them engaged in the task of "word-translation" while negotiating a "syntactical maze" (1958: 121). On this account, the intervening process would mainly consist of linguistic correspondence - as applied, with dismal results, in early machine translation.

In information-theoretical terms (i.e. based on the view of language as a code), the linguistic conversion process would also be referred to as 'transcoding' or code switching, that is, decoding and subsequent (re-)encoding by the (human or automatic) translator. And yet, though they readily embraced the new communication-theoretical terminology, translation theorists as well as psycholinguists were aware that the human processor applied storage, chunking and retrieval operations under some strategic control (e.g. Kade and Cartellieri 1971, Kirchhoff 1976a/2002).

The elucidation of such processes inside the 'human information processor' was a task cut out for psychologists who dared pry open the 'black box' closed off to speculation by their behaviorist predecessors. The fact that this effort was undertaken not to study the (written) translation process - at least not until one-and-a-half decades later - but to study (simultaneous) interpreting had a profound influence on the course of interpreting research. The work of David Gerver (1971), first published in this journal thirty years ago (Gerver 1975), did much to establish the view of interpreting as "a form of complex human information processing involving the perception, storage, retrieval, transformation, and transmission of verbal information" (1975: 119) that is widely held in the interpreting (research) community to this day.

Intriguingly, Gerver's work in the 1970s was not the only 'psychological approach' to interpreting: Danica Seleskovitch, a pioneer professional and interpreter trainer, sought to explain the process of interpreting even in her earliest, largely professionoriented publications (e.g. Seleskovitch 1962). Though naturally aware that conference interpreters were there to provide a professional service enabling communication in a particular institutional setting, her main interest lay in the mental process leading from the speaker's utterance to the interpreter's rendition. Seleskovitch and her associates thus shared a keen interest with psychologists in cognitive structures and processing operations, such as short-term memory and knowledge use (cf. Seleskovitch 1975, 1976); methodologically, however, the group around Seleskovitch was wary of psychological experimenting and generally made the gap between the psychologists' and their own paradigm appear wider than, in hindsight, was actually the case. Much effort was expended on reaffirming Seleskovitch's theory of the process - the knowledge-mediated grasping of (language-independent) 'sense' as a basis for natural reexpression in another language, which remained on a rather basic level of explanation (cf. García-Landa 1995: 392). It was not until the late 1980s that, according to 
Gile (1994b), the experimental study of cognitive processes in interpreting in the tradition of Gerver enjoyed a "Renaissance," and this cognitive-processing paradigm has been going strong ever since.

One of the strands that was to feed into it was text linguistics, which emerged roughly at the same time as the work of Gerver and the Paris School, i.e. in the late 1970s. Scholars like Robert de Beaugrande (1980) readily embraced recent insights by cognitive scientists into natural language processing and developed a distinctly procedural (process-oriented) view of text comprehension and production. Aspects of textuality like coherence, acceptability and intertextuality proved influential to a significant set of research based on the conceptualization of interpreting as 'text processing' (e.g. Kohn and Kalina 1996).

Despite an ever broader definition of 'text' - from an initial concern with intersentential pronominal reference to the comprehensive notion of 'text' as a 'communicative event' (Beaugrande and Dressler 1981), text-linguistic approaches to the study of interpreting did not yet engage with the full dynamics of (mediated) communication. It was the kindred notion of 'discourse' that was to serve as the more encompassing label, inspiring many to look beyond linguistic structures for insights into the communicative process. Another line of thought on the nature of the process in human interaction emerged from translation theorists in Germany, as described in more detail below.

\section{What's (in) a Process?}

\subsection{The process(ing) supermeme}

The various conceptualizations of interpreting outlined above may differ widely with regard to their origins and theoretical frameworks; nonetheless, they all share a basic view of interpreting as a 'process.' In the case of interpreting as a 'verbal transfer,' the process implies an operation on linguistic input; those viewing interpreting as 'making sense' stress the cognitive (knowledge-based) component of language processing, as do researchers approaching interpreting as a 'cognitive information processing skill'; interpreting as 'text production' likewise foregrounds linguistic features and processes, though with increasing sensitivity to the role of the communicative context. In Chesterman's (1997) terms, the notion of 'process,' or 'processing,' could therefore be regarded as a "supermeme" in interpreting studies - an influential idea that is so pervasive as to shape all scholarly reflection and analysis.

And yet, even the broad notion of 'process' could be said to be not broad enough. At least up until the late 1980s, 'process' appears to have been construed in the narrower sense illustrated in Figure 1 - as a forward movement from one point to another involving some kind of transformation of input into output. This view of the process, and the development of a much more comprehensive understanding, can be discussed with reference to various process models of interpreting.

\subsection{Tripartite models}

The constituents of the process, whether linguistic units or mental constructs, have often been modeled in a tripartite structure. This is illustrated in Figure 2 for the well-known triangular process model by Seleskovitch. 


\section{FIGURE 2}

Triangular model of the interpreting process (adapted from Seleskovitch and Lederer 1984: 185)

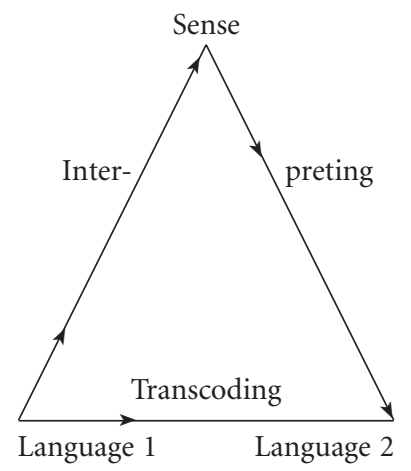

This simple model of the interpreting (and translation) process, which can be traced back to the early 1960s (Seleskovitch 1962: 16), has been elaborated on by various authors. García-Landa (1981), for instance, added memory components and specific terminology (e.g. "discourse acts"), and Colonomos (cited in Ingram 1985: 99) offered an adaptation to the process of sign language interpreting, with a variant for the process of transliteration. Even the rich model proposed by Setton (1999) could be said to reflect Seleskovitch's fundamental triangular structure.

Though all these authors would naturally be aware that the process was driven by human agents such as a speaker, listeners, and the interpreter, these constituents of the process were hardly ever represented explicitly in the models (but see Seleskovitch and Lederer 1984: 168). A more agent-centered view could conceivably have come from psychology, but did not. Apart from an isolated contribution from sociology (Anderson 1976), it was mainly translation theorists who helped extend the scope of process models of translational activity by foregrounding the role of the human actors.

In the same year that Bruce Anderson (1976) published his pioneering account of the interaction constellation(s) in interpreting, Hella Kirchhoff (1976b), a veteran teacher of interpreting at the University of Heidelberg, adapted work by German translation scholar Katharina Reiss to model interpreting as a "three-party two-language communication system" (Fig. 3).

Though couched in the terminology of communication theory, with a "code," "sender," and "receiver," Kirchhoff's model shows how the message, which comprises a verbal as well as a nonverbal component, is expressed by the speaker in a particular situational context, which is in turn shaped by a given socio cultural environment. The interpreter is envisaged as a bridge between the situational and socio cultural backgrounds of the source and target languages, but outside the communicative situation shared by the primary parties.

Kirchhoff's model may appear rather static and unidirectional, but it clearly points the way toward a reconceptualization of interpreting (and translation) as a process of (inter)action in a given situational and socio cultural environment. The driving force in this conceptual reorientation was Hans Vermeer, a colleague of 
FIGURE 3

Three-party two-language model of interpreting (adapted from Kirchhoff 1976b)

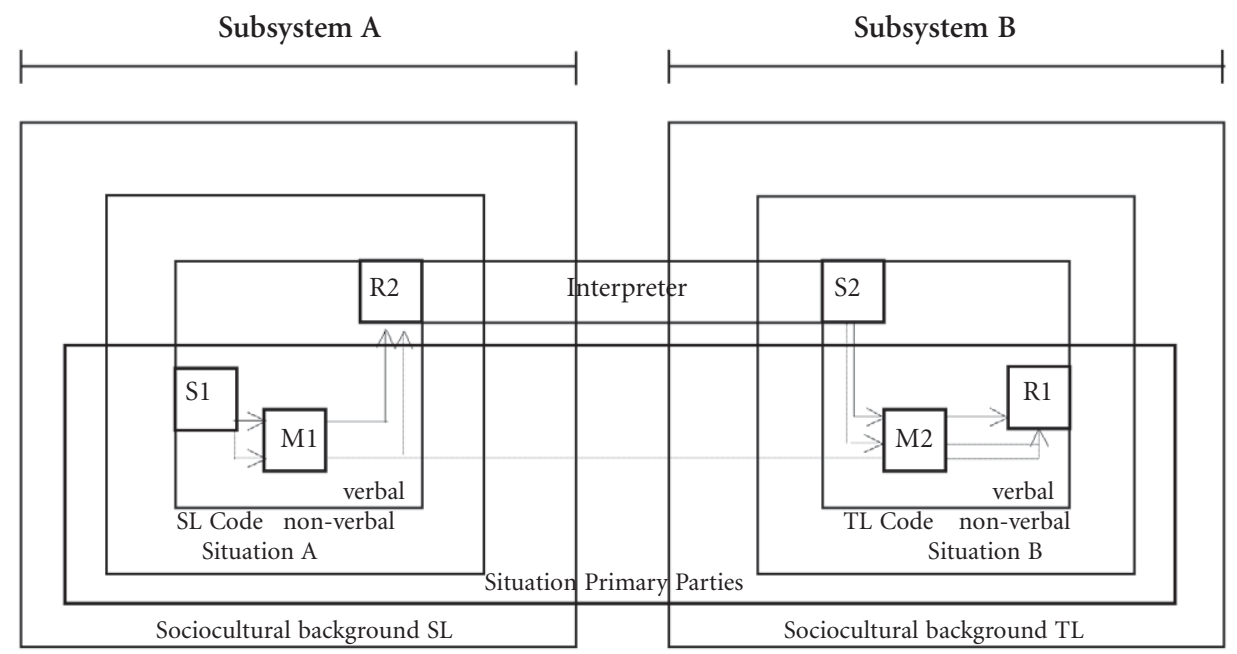

Kirchhoff's at the University of Heidelberg. In his skopos theory (Reiss and Vermeer 1984), translation (including interpreting) was analysed in the framework of action theory, and thus described as a goal-directed process in a given situation (see also Nord 1997). Viewing interpreting as a form of action gives pride of place to the purpose that is to be achieved as well as to the baseline situation that shapes the process and will in turn be shaped by it. Asking 'what is in the process' therefore requires a thorough answer to the question of 'what is in the situation.' Based on Vermeer's (1989) groundwork, I attempted to give such an answer in my analysis of simultaneous interpreting (Pöchhacker 1992, 1994). A few insights gained from that modelling effort may be worth restating here.

Most fundamental is the recognition that the 'situation' in which interpreting takes place does not exist as anything objective - a novel idea to the naïve empirical researcher which has of course long become a truism in post-modern (non-essentialist) epistemology. The challenge of specifying what the situation 'is' therefore becomes immense: The presence of human beings as integral parts of the communicative situation makes a characterization in terms of time and place grossly insufficient; it is the human actors that need to be accounted for, and this requires a knowledge-based perception from someone's particular point of view. The situation, then, is a matter of perspective. More than the physical 'angle of vision' (though a person's current physiological perception and disposition certainly play a crucial part), perspective here refers to the psychological outlook on the situation: This subjective perspective on the situation, i.e., its assessment and a certain intentional and emotional attitude (orientation) toward it, is shaped by a person's cognitive background (horizon). The latter is essentially conditioned by the social and cultural environment(s) in which a person has been socialized, or enculturated, and, at the same time, the totality of a 
person's knowledge and know-how can be said to make up his or her identity as a member of a socio-culture.

In social contacts, what is 'visible' to others is not so much the socio cultural cognitive background but the role in which a person appears in the interaction. As a fundamentally relational construct, the role cannot be specified per se: a chairperson, speaker, respondent, etc. only takes up the role in question vis-à-vis other persons and, crucially, their expectations. These expectations will again be shaped by the cognitive-cultural background and perspective of the 'other(s)' in the interaction, and the other interactant(s) will be subject to the kind of assessment and orientation that makes up every individual perspective on the situation.

As complicated as this may sound, it is certainly no more than a faint approximation of the intricate perceptual, cognitive and cultural interrelations that shape communicative interaction even before a verbal utterance takes place. This complex mutuality holds true for the 'simple' case of interpersonal communication in one language and is obviously multiplied in the case of mediated communication, with at least three interacting parties (i.e. the primary parties and the interpreter), roles and socio cultural backgrounds. The interpreter's perspective on the situation, which will be shaped by what s/he knows about the interacting parties, their roles, goals, attitudes, previous contacts, etc., is a sort of meta-perspective as it also needs to include the assessment and orientation of the primary parties toward each other (though these will of course form an assessment and expectation of the interpreter, too). The view of interpreting as 'mediation,' which is a more recent conceptualization than the traditional process-oriented views sketched out in section 2 (cf. Pöchhacker 2004: 59), is obviously highly germane to the situation model of interpreting in a process of triadic interaction, as visualized in Figure 4.

The 'interactant model of the situation' (Fig. 4) seeks to show the multiple dynamic relationships which make up the communicative situation as it 'exists' for a given interactant and shapes his or her communicative behaviour. It should be clear that the constellation of interaction, as specified, for instance, in Kirchhoff's (1976b) model, is by no means static; the arrows issuing from the individual participants are meant to indicate that social interaction is an intrinsically dynamic process, with multiple cognitive and emotional interrelations that keep changing as the interaction proceeds.

The crucial role of the 'situation' suggested by Vermeer's action-theoretical conception of communicative interaction can thus be used to foreground the nature of communication as a process. This overall process involves a multitude of (sub)processes, all of them mediated by the individual's cognitive background, in the widest sense. Interpreting, then, is a process involving many constituent processes in the (prototypically) triadic process of interaction.

If we accept that mediated communication as such needs to be regarded as a (complex) process, we can go one step further and position it in an even broader theoretical framework. 
FIGURE 4

Interactant model of the interpreting situation

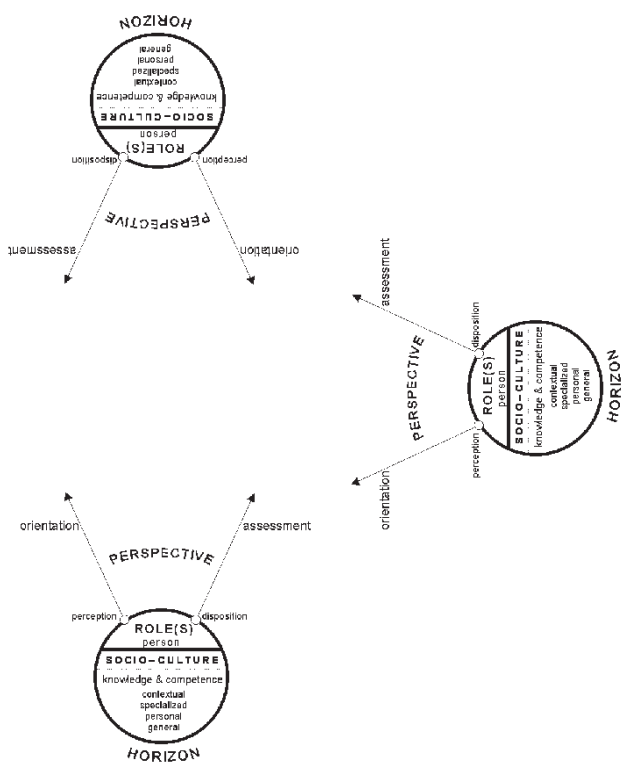

\subsection{Beyond communication}

In various process-oriented conceptions of interpreting, the task of the interpreter is merely to process (verbal) utterances. While a verbal-transfer view would foreground the linguistic components, a cognitive-processing perspective would focus on mental structures and operations, and interpreting as 'making sense' would highlight the (language-independent) conceptual representation, all of these accounts of the process start with the interpreter's 'input.' Even approaches to interpreting as (targetoriented) text production may limit the scope of the process to the transformation of a source text into a target text. In contrast, viewing the interpreter as an interactant enabling communication between primary parties in a process of interaction offers a much broader analytical framework. Even so, the tripartite model shown in Figure 4 fails to represent higher-order variables that may have a decisive impact on what transpires in the interaction.

Complementing Vermeer's skopos theory, the overarching constraints on translation were first analyzed by Justa Holz-Mänttäri (1984) in her "theory of translatorial action" (translatorisches Handeln). Drawing on her personal experience as a translator as well as on insights from systems theory and other fields, Holz-Mänttäri stressed the translator's subordinate role in his or her employer's strategic professional activities. When communication across languages and cultures is needed for some transactional purpose (such as informing, selling, instructing, entertaining), the client will commission the translator as an expert professional to produce a (target) text as required - not as an end in itself but for use in a certain transaction.

Though Holz-Mänttäri's (1984) work is not primarily geared to interpreting, it is easy to see how her model of the network, or 'system,' of (inter)action applies to the interpreting process: the interpreter's relation with the professional client (employer), 
the specification of the assignment, and the ultimate purpose of communication in a given institutional setting are significant forces driving the process of interaction over and above a particular 'input text.' In my analysis of simultaneous conference interpreting (Pöchhacker 1994, 1995), I have referred to the level of the overall communicative event, i.e. the conference, as the 'hypertext.' With regard to dialogue interpreting, this notion seems no less relevant: judicial proceedings, a therapy session, an asylum hearing, a live TV interview - all of these communicative events involve institutional constraints and functional concerns at the hypertext level that shape the interpreter's task and actions.

Though not a chief source of inspiration for Vermeer's and Holz-Mänttäri's action-theoretical approach, concepts from sociology can easily be brought to bear on the study of translatorial activity. Holz-Mänttäri (1984) draws on the analysis of social relations in terms of division of labour and adopts the notion of "reflexive co-orientation" (Siegrist 1970) for the micro-sociological analysis of cooperative interaction. More indirectly, Vermeer incorporated socio-linguistic insights from paradigms such as the ethnography of communication (e.g. Gumperz and Hymes 1972), which came to be more fully embraced by interpreting scholars in the course of the 1990s. Indeed, the functionalist concern with action - and, less explicitly, interaction - in the study of translation was only one developmental strand that gave rise to a broader view of interpreting as a process. Approaches from socio-linguistics, sociology and communication studies led to several significant proposals for a more comprehensive sort of process-orientation in the study of interpreting.

\section{Toward an Integrated View}

The question asked in the heading of section 3 - "What's (in) a process?" - would normally call for an answer in the form of a definition. Instead, the preceding paragraphs dealt with theoretical constructs and models, and the notion of 'process' was given an ever more extensive interpretation. High time, then, at least at this point, to check the various meanings attributed to the concept of 'process' against lexicographic authority before we attempt to draw together various conceptual proposals.

\subsection{A process is ...}

Webster's (1986) Third New International Dictionary offers a wealth of definitions. Aside from more technical uses, a 'process' is described most generally as a "continued onward flow," or "course"; as "something (as a series of actions, happenings, or experiences) going on or carried on"; and as "the action of continuously going along through each of a succession of acts, events, or developmental stages" (1986: 1808). All of these definitions leave ample room for the broad interpretation developed in section 3, where a 'process' was characterized not (only) as a set of specified operations but as a course of (human) action(s).

In one of his later writings, Vermeer (1996) devoted a 75-page essay to the theme of "The World as a Process." Maintaining his focus on the theory of translatorial action, he uses both anecdote and abstraction to first argue for a relativistic epistemology which rules out the existence of an "objective truth" in (communicative) interaction (cf. 1996: 87). The notion of 'process' is then seen as "constituted by a 
sequence of analytically distinguishable sets of events which, under specifiable conditions, can be related to one another" (Vermeer 1996: 205; my translation). Several pages later he offers a more straightforward definition of 'process' as "an event in time" (1996: 213). Either way, his quasi-philosophical reflections are well in line with the widely accepted usage recorded in the dictionary. And yet, this broad understanding of 'process' is rather exceptional, at least in the field of interpreting studies to date.

\subsection{Process as practice}

One of the few authors who pointed interpreting scholars in the direction of a wider sense of 'process' is Per Linell (1997). Speaking from the perspective of communication studies (at the 1994 Turku Conference on Interpreting), Linell (1997: 50) posited the "product," or "text," and the "process" as the two main subdivisions in the study of language use ("discourse"), as shown in Figure 5.

FIGURE 5

Linell's (1997: 50) conceptual analysis of language and process

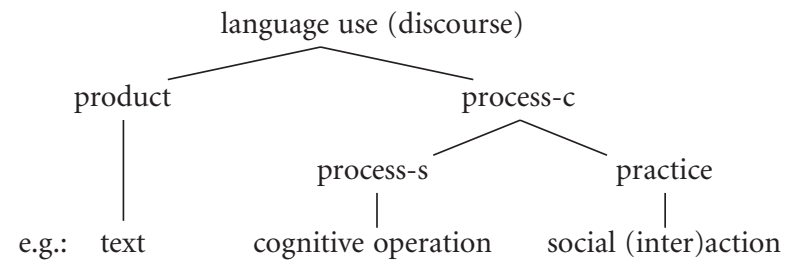

Under the generic notion of 'process' (process-c $=$ comprehensive), Linell distinguishes between "process" in the more specific sense (process-s) and "practice," and differentiates them as follows:

Process-s refers to the implementation of predefined operations (input-output processing), most often viewed as cognitive intra individual processes in real time. (...) The concept of practice, on the other hand, emphasizes active and interactive problem solving in situational and cultural contexts. (Linell 1997: 50)

While Linell's analysis reaffirms the potentially wide scope of a process-oriented view, his juxtaposition of process as cognitive operation versus practice as social (inter)action seems to impose stricter boundaries than may be necessary or useful. In particular, Linell's (1997: 50) subsequent assertion that "Practice, but not process-c, emphasizes meaningful and purposeful action" is difficult to reconcile with a view of the interaction process in which each interactant is characterized by his or her intentional orientation and outlook on the communicative situation (cf. Fig. 4). Moreover, when Linell later on suggests that the three "'discourse-oriented' concepts of text, process and practice (...) highlight and fit different forms of T\&I," and goes on to relate "text" to (written) translation, "process" to simultaneous interpreting, and "practice" to dialogue (consecutive) interpreting (Linell 1997: 60-61), the discrepancy with a comprehensive conception of (any) translational activity as a situated process of social - and intercultural - (inter)action become regrettably clear. It is nowadays widely accepted to regard translation and interpreting as a 'social practice,' 
just as it has become rather awkward to refer to a conference interpreter as "an asocial information-processing system" (Linell 1997: 61).

This criticism notwithstanding, Linell's overall proposal for a "dialogic," "socialinteractionist" framework for the study of "human action, meaning, and sense-making” (1997: 64) deserves special acknowledgement. After all, it is this theoretical environment which nurtured the influential work of Cecilia Wadensjö on dialogue interpreting as interaction (cf. Linell et al. 1992). It was Wadensjö (1992) who found contemporary translation theories - including the German functionalist approach to be biased toward "monologic" text production and not sensitive enough to the dynamics of interpersonal communication in triadic interaction. Wadensjö (1992, 1998), who drew on concepts from interactional socio-linguistics (e.g. Goffman 1981) and other sociological and socio-linguistic approaches, established a paradigm of interpreting research that offered a close fit with both the emerging professional domain of community interpreting and the sociolinguistic study of interpreting as advanced by sign language interpreting researchers in the US (e.g. Cokely 1992, Roy 2000). Cynthia Roy's $1989 \mathrm{PhD}$ thesis on “interpreting as a discourse process" (Roy 2000), in particular, extended the shared ground of the dialogic interactionist paradigm by foregrounding the notion of discourse as a process and social practice (cf. van Dijk 1997).

\subsection{Cognition in context}

The interaction model of interpreting outlined in section 3.2 and the dialogic interactionist paradigm discussed in section 4.2 above go to show that, analytically at least, there is not a principal difference between simultaneous (conference) interpreting and (consecutive) dialogue interpreting. Rather, these prototypical forms of interpreting can easily be subsumed under a single analytical framework in which interpreting is construed first and foremost as a situated process of social interaction. What may seem more difficult to reconcile is the duality between the overall discourse process and the cognitive processing operations. Here again, though, there are some theoretical and methodological proposals that can help overcome a dichotomous view.

Robin Setton's (1999) “cognitive-pragmatic analysis” of simultaneous interpreting, for instance, incorporates the cognitive processing operations performed on the (multi-modality) input into a relevance-theoretical framework in which understanding (and expression) crucially depend on the context of communication: Mediated by relevant world knowledge and situational knowledge, a mental representation of the discourse is built up and kept current as the communicative interaction unfolds. The (verbal, situational, institutional) context thus cannot be separated from the cognitive processing of (verbal and other) input; context is cognition, and cognition is invariably situated (cf. Clancey 1997, Clark 1997).

While accepting the fact that interpreting is a situated activity system that should require less effort than doing the same for (written) translation (cf. Risku 2002), previous models of interpreting as a process have indeed tended to privilege 'psycholinguistic cognition' over 'socio-psychological cognition.' The (inter)actiontheoretical account of translational activity foregrounded in this paper should therefore lead us to conclude that the influential idea of interpreting as a 'process' applies 
- and ought to be applied by the researcher - at many interdependent levels of analysis: interpreting as a process involving a multitude of cognitive (sub)processes takes place within a process of situated interaction as part of a particular social practice. Given the inherently subjective nature of an interactant's cognitive representation of the situational context, process-orientation in interpreting studies must be underpinned, in Linell's (1997) terms, by a 'social-constructionist' or 'contextualist' epistemology - without forgetting, however, that any social construction of context is a matter of cognition. Interpreting as a 'socio-cognitive process,' then? Theoretical and empirical research in future years will show to what extent a more comprehensive process-orientation will facilitate progress in interpreting studies.

\section{Conclusion}

As reviewed in this paper, the idea of interpreting as a process, and of interpreting research as necessarily process-oriented, is all but ubiquitous in interpreting studies. As I have pointed out, however, the notion of process has traditionally been construed rather narrowly, with a focus on the micro-level of cognitive processing operations rather than the macro-process of social interaction. In a discussion of various models of interpreting (with a strong bias toward the (inter)action-theoretical framework advanced by German translation scholars in the 1980s), I have tried to show that adopting a broader notion of 'process' - as a progressive course or event in time can help achieve a more holistic, 'real-life' understanding of the phenomenon. This comes at the cost of using the term 'process' very liberally, for anything from memory storage to mediation; but it comes with the benefit of approaching interpreting in a coherent conceptual framework, reconciling situated (inter)action and mental operations in a socio-cognitive perspective.

\section{REFERENCES}

Anderson, R. B. W. (1976): "Perspectives on the Role of Interpreter," Translation: Applications and Research (R. W. Brislin, ed.), New York, Gardner Press, p. 208-228.

Beaugrande, R. de (1980): Text, Discourse, and Process, Norwood NJ, Ablex.

Beaugrande, R. De and W. U. Dressler (1981): Introduction to Text Linguistics, London, Longman.

Chesterman, A. (1997): Memes of Translation: The Spread of Ideas in Translation Theory, Amsterdam and Philadelphia, John Benjamins.

Clancey, W. J. (1997): Situated Cognition. On Human Knowledge and Computer Representations, Cambridge, Cambridge University Press.

Clark, A. (1997): Being There. Putting, Brain, Body, and World Together Again, Cambridge, MIT Press.

Cokely, D. (1992): Interpretation: A Sociolinguistic Model, Burtonsville MD, Linstok Press.

García-Landa, M. (1981): "La 'théorie du sens,' théorie de la traduction et base de son enseignement," L'enseignement de l'interprétation et de la traduction: de la théorie à la pédagogie (J. Delisle, ed.), Ottawa, University of Ottawa Press, p. 113-132.

- (1995): "Notes on the Epistemology of Translation Theory," Meta, 40-3, p. 388-405.

Gerver, D. (1971): Aspects of Simultaneous Interpretation and Human Information Processing, D.Phil. thesis, Oxford University.

Gerver, D. (1975): "A Psychological Approach to Simultaneous Interpretation,” Meta, 20-2, p. $119-128$. 
GiLe, D. (1994a): “Methodological Aspects of Interpretation and Translation Research,” Bridging the Gap: Empirical Research in Simultaneous Interpretation (S. LAmbert and B. MoserMercer, eds.), Amsterdam and Philadelphia, John Benjamins, p. 39-56.

Gile, D. (1994b): “Opening Up in Interpretation Studies," Translation Studies - An Interdiscipline (M. Snell-Hornby, F. Pöchhacker and K. Kainde, eds), Amsterdam and Philadelphia, John Benjamins, p. 149-158.

GLÉMET, R. (1958): “Conference Interpreting,” Aspects of Translation (A. H. Smith, ed.), London, Secker and Warburg, p. 105-122.

Goffman, E. (1981): Forms of Talk, Oxford, Basil Blackwell.

Goldman-Eisler, F. (1972): "Segmentation of Input in Simultaneous Translation," Journal of Psycholinguistic Research, 1-2, p. 127-140.

Gumperz, J. J. and D. Hymes, eds. (1972): Directions in Sociolinguistics, New York, Holt, Rinehart and Winston.

Hermann, A. (1956/2002): “Interpreting in Antiquity," The Interpreting Studies Reader (F. PöchHACKer and M. Shlesinger, eds), London and New York, Routledge, p. 15-22.

Holz-MäntтÄri, J. (1984): Translatorisches Handeln. Theorie und Methode, Helsinki, Suomalainen Tiedeakatemia.

Ingram, R. M. (1985): "Simultaneous Interpretation of Sign Languages: Semiotic and Psycholinguistic Perspectives," Multilingua, 4-2, p. 91-102.

Kade, O. and C. Cartellieri (1971): "Some Methodological Aspects of Simultaneous Interpreting," Babel, 17-2, p. 12-16.

Kirchноғғ, H. (1976a/2002): "Simultaneous Interpreting: Interdependence of Variables in the Interpreting Process, Interpreting Models and Interpreting Strategies," The Interpreting Studies Reader (F. Pöchhacker and M. Shlesinger, eds.), London and New York, Routledge, p. 111-119.

Kirchнoff, H. (1976b): "Das dreigliedrige, zweisprachige Kommunikationssystem Dolmetschen," Le Langage et l'Homme, 31, p. 21-27.

KoHn, K. and S. Kalina (1996): “The Strategic Dimension of Interpreting," Meta, 41-1, p. 118-138.

Linell, P. (1997): “Interpreting as Communication," Conference Interpreting: Current Trends in Research (Y. Gambier, D. Gile, and C. Taylor, eds.), Amsterdam and Philadelphia, John Benjamins, p. 49-67.

Linell, P., C. Wadensjö and L. Jönsson (1992): "Establishing Communicative Contact Through a Dialogue Interpreter," Communication for Specific Purposes / Fachsprachliche Kommunikation (A. Grindsted and J. Wagner, eds.), Tübingen, Gunter Narr, p. 125-142.

Nord, C. (1997): Translating as a Purposeful Activity, Manchester, St Jerome Publishing.

Pöchнacker, F. (1992): “The Role of Theory in Simultaneous Interpreting," Teaching Translation and Interpreting. Training, Talent and Experience (C. Dollerup and A. LoddegaArd, eds), Amsterdam and Philadelphia, John Benjamins, p. 211-220.

Pöchhacker, F. (1994): Simultandolmetschen als komplexes Handeln, Tübingen, Gunter Narr.

PöchнаскеR, F. (1995): “Simultaneous Interpreting: A Functionalist Approach," Hermes. Journal of Linguistics, 14, p. 31-53.

PöchHacker, F. (2004): Introducing Interpreting Studies, London and New York, Routledge.

Reiss, K. and H. J. Vermeer (1984): Grundlegung einer allgemeinen Translationstheorie, Tübingen, Niemeyer.

Risku, H. (2002): “Situatedness in Translation Studies," Cognitive Systems Research, 3, p. 523-533.

Robinson, D., ed. (1997): Western Translation Theory, Manchester, St Jerome Publishing.

Roy, C. B. (2000): Interpreting as a Discourse Process, Oxford, Oxford University Press.

Schleiermacher, F. (1813/1997): "On the Different Methods of Translating," Western Translation Theory (D. Robinson, ed.), Manchester, St Jerome Publishing, p. 225-238.

Seleskovitch, D. (1962): "L'interprétation de conférence," Babel, 8-1, p. 13-18.

Seleskovitch, D. (1975): Langage, langues et mémoire. Étude de la prise de notes en interprétation consécutive, Paris, Minard Lettres Modernes. 
Seleskovitch, D. (1976): “Interpretation, A Psychological Approach to Translating," Translation: Applications and Research (R. W. Brislin, ed.), New York, Gardner Press, p. 92-116.

Seleskovitch, D. and M. Lederer (1984): Interpréter pour traduire, Paris, Didier Érudition.

Setton, R. (1999): Simultaneous Interpretation: A Cognitive-Pragmatic Analysis, Amsterdam and Philadelphia, John Benjamins.

Siegrist, J. (1970): Das Consensus-Modell. Studien zur Interaktionstheorie und zur kognitiven Sozialisation, Stuttgart, Enke.

Treisman, A. (1965): "The Effects of Redundancy and Familiarity on Translating and Repeating Back a Foreign and a Native Language," British Journal of Psychology, 56, p. 369-379.

van Dijк, T. A., ed. (1997): Discourse as Social Interaction. Discourse Studies: A Multidisciplinary Introduction. Vol. 2, London, Thousand Oaks and New Delhi, Sage.

Vermeer, H. J. (1989): Skopos und Translationsauftrag, Heidelberg, Universität Heidelberg.

Vermeer, H. J. (1996): Die Welt, in der wir übersetzen, Heidelberg, TEXTconTEXT-Verlag.

Vermeer, H. J. (1998): Interpreting as Interaction, London and New York, Longman.

WADENSJÖ, C. (1992): Interpreting as Interaction. On Dialogue Interpreting in Immigration Hearings and Medical Encounters, Linköping, Linköping University, Department of Communication Studies.

Webster's (1986): Third New International Dictionary of the English Language, Springfield MA, Merriam-Webster.

WirL, J. (1958): Grundsätzliches zur Problematik des Dolmetschens und des Übersetzens, Vienna, Wilhelm Braumüller. 